Sharif University of Technology
Scientia Iranica
SCIENTIA
I RAN I C A

Research Note

\title{
Effects of petrochemical wastes incinerator ash powder instead of Portland cement on the properties of concrete
}

\author{
D. Mostofinejad ${ }^{\mathrm{a}}$, S. Noorpour ${ }^{\mathrm{b}, *}$, M. Noorpour ${ }^{\mathrm{c}}$, R. Karbati Asl ${ }^{\mathrm{c}}$, \\ V. Sadeghi Balkanlou ${ }^{c}$ and A. Karbati Asl ${ }^{\text {d }}$ \\ a. Department of Civil Engineering, Isfahan University of Technology, Isfahan, Iran. \\ b. Department of Civil Engineering, Tabriz Branch, Islamic Azad University, Tabriz, Iran. \\ c. Young Researchers and Elite Club, Tabriz Branch, Islamic Azad University, Tabriz, Iran. \\ d. Department of Project Management, Payame Noor University, Iran. \\ Received 17 June 2015; received in revised form 7 February 2016; accepted 25 April 2016
}

\section{KEYWORDS}

Concrete;

Incinerator ash;

Compressive strength;

Splitting-tensile

strength;

Flexural strengths;

Elastic modulus.

\begin{abstract}
Petrochemical wastes incinerator ash is generated from industries in which the landfill is the last step for their flowing. This research was performed for waste management of ash and its possible large-scale utilization in making concrete. An experimental investigation carried out to evaluate the mechanical properties of concrete mixtures in which Portland cement type II was partially replaced with Petrochemical Complex Incinerator Ash Powder (PCIAP). The cement was replaced with various amounts of PCIAP, i.e. $5 \%$, $10 \%, 15 \%, 20 \%$, and $25 \%$. Tests were performed on the properties of fresh concrete as well as hardened concrete. Compressive, splitting tensile and flexural strengths, and modulus of elasticity were determined in 7,28 , and 90 days. Test results indicated that by using PCIAP as partial replacement of cement, stabilization, solidification, and neutralization treatment processes for the industrial wastes management were carried out, and the test results of the mixture M-2 (5\% PCIAP) indicated that it can be used to make concrete which is lighter than normal concrete and heavier than structural lightweight aggregate concrete.

(C) 2017 Sharif University of Technology. All rights reserved.
\end{abstract}

\section{Introduction}

Some products of petrochemical industries include raw plastics. Different units of these industries generate wastes with high toxic compounds. Some petrochemical industries use incineration system to optimize their wastes since it reduces the volume of waste tremen-

*. Corresponding author. Tel/Fax:: +984132808794; E-mail addresses: dmostofi@cc.iut.ac.ir (D. Mostofinejad); S.Noorpour@yahoo.com (S. Noorpour); M.Noorpour@yahoo.com (M. Noorpour); R.Karbati@yahoo.com (R.Karbati Asl); v.sadeghi2009@gmail.com (V. Sadeghi Balkanlou); uniquea88k@yahoo.com (A. Karbati Asl) dously and destroys the toxic compounds of wastes. Petrochemical Complex Incinerator Ash (PCIA) is obtained after incineration of petrochemical wastes. PCIA is ground to ease its reaction with Portland cement and is termed as Petrochemical Complex Incinerator Ash Powder (PCIAP). It has inherent pernicious effects, which is why it disposes in landfills. Since cement production causes environmental costs such as use of natural resources, air pollution, and energy consumption, research on the possible use of PCIAP as a cement substitution seems beneficial and necessary. Most common methods of waste management include neutralization, Stabilization, and Solidification (S/S). Neutralization is a method that a reactor, such as 
cement, Pozzolan, lime, improved clay, organic thermo set, thermo plastic, organic polymer, and silicate, decreases toxic properties of contaminants and immobilizes the contaminants [1]. Solidification is a method that sticks a polluted media with a reagent, changes contaminants' physical properties, and constitutes a solid substance. Also, stabilization is a method that decreases the mobility of contaminants with a chemical reaction [2]. Partial substitution of PCIAP for cement in concrete results in its neutralization and $\mathrm{S} / \mathrm{S}$ as well.

Over the past few years, utilization of bottom ash or incinerator ash as partial substitution of aggregates [3], as an aggregate substitution in asphalt mixes $[4,5]$, as a substitute for cement $[6,7]$, as a substitution for natural aggregates in structural grade concrete $[8,9]$, as an aggregate replacement in highway and roads construction $[10,11]$, and as a soil stabilizing agent [12] has been the subject of several investigations. $\mathrm{S} / \mathrm{S}$ is an effective technology to treat hazardous wastes according to United States Environmental Protection Agency [13] in low-level radioactive waste [14] in variety of industrial wastes [14] and in contaminants that include metals [15].

Juric et al. [7] reported that bottom ash can be used as a substitution forcement in concrete for the sake of $\mathrm{SiO}_{2}$ and $\mathrm{CaO}$ inclusion. Forteza et al. [16] concluded that engineering properties of bottom ash are like natural aggregates, and they can be used in road construction. Cement is a common binder in S/S technology and cement solidification is mainly used for inorganic contaminants [15]. Also, wastes trap within gel structure and calcium hydroxide trap in pores [17]. Pecqueur et al. [18] indicated that the use of Municipal Solid Waste Incinerator (MSWI) bottom ash as embankments in road construction may cause pavement cracking and expansion due to chemical reaction, but it is solvable with Portland cement up to $70 \%$.

Ferraris et al. [19] reported that vitrified bottom ashes can be used as filler instead of cement up to $20 \%$ and as a substitute for natural aggregate up to $75 \%$ vol. Kikuchi [20] demonstrated that Municipal Solid Waste Incinerator Ash (MSWIA) can partially be replaced with the cement as raw materials up to $50 \%$. Saikia et al. [21] indicated that raw municipal solid waste incineration fly ash-based clinkers are more reactive than the washed Municipal Solid Waste (MSW) ash based clinkers. Use of incinerator fly ash as substitution of cement in concrete was studied by Taha et al. [6]. They indicated that concretes made by incinerator fly ash achieved low compressive strength at the ages of 3 to 6 months; however, the specimens attained higher compressive strength after six months due to increasing pozzolanic reaction with the passage of time. $\mathrm{S} / \mathrm{S}$ is recognized as the best demonstrated available technology in treating hazardous wastes [22].
Pan et al. [23] indicated that cement production can be a feasible substitution for MSWIA management and does not have any impact on the compressive strength of the clinker. Other researchers reported that low amounts of bottom ash can be used in kilns as a raw material since it includes chloride [24,25]. Use of MSWI fly ash as a raw material in sintering sulphoaluminate cement clinker was studied by Shi et al. [26]. They reported that although sulphoaluminate cement have higher compressive strength in early ages, it improves smoothly at later ages. It is also proved that concrete incorporating Fly Ash (FA) exhibits either similar or enhanced performance in comparison to Portland cement [6].

Utilization of MSWI ash in concrete [27] and in cement and mortar [28] was also reviewed. Municipal solid waste incineration fly ash was examined for different applications in concrete $[29,30]$. Kula et al. [31] reported that fly ash and coal bottom ash can be used as a high volume cement replacement in the production of concrete. MSWI ash or bottom ash was used for different applications; for instance, as raw materials for clinker production [32] and for cement production $[20,21,23,33]$, as aggregates in nonstructural concrete [34], as controlled low-strength materials in trench construction [35] and in the production of polymer concrete [36], as aggregates in road construction and in concrete $[16,37,38]$, as in the form of glass-like as natural aggregates in mortar and concrete [19], in tile production [39], and in glass ceramic products [40].

Fly ash and other waste materials have been reported recently which are considered as one of remarkable materials that have shown a good potential in enhancing the strength and thermal properties of cementitious materials. However, the effects of PCIAP on the performance and properties of cement-based materials have been neglected in previous research studies. This research investigates the possibility of using PCIAP as cement substitution in concrete to treat it with methods of S/S and neutralization, as this material has substantial economic and environmental benefits. To reach this goal, engineering properties of the concrete mixtures made with PCIAP are tested. This study also attempts to answer the question of whether or not PCIAP creates drawbacks as well as advantages in concrete.

\section{Experimental program}

\subsection{Materials}

Portland cement type II was used according to ASTM C150 [41]. Physical properties and also chemical compositions of cement are given in Tables 1 and 2, respectively [42]. PCIA was obtained by the burning of petrochemical wastes. The physical properties and 
Table 1. Physical properties of Portland cement [42].

\begin{tabular}{lcc}
\hline \multicolumn{1}{c}{ Physical test } & $\begin{array}{c}\text { Results } \\
\text { obtained }\end{array}$ & $\begin{array}{c}\text { ASTM C150 } \\
\text { (type II cement) }\end{array}$ \\
\hline Air content of mortar, volume (\%) & 5.54 & 12 max \\
Fineness: specific surface (air permeability test) $\left(\mathrm{m}^{2} / \mathrm{kg}\right)$ & 281 & $280 \mathrm{~min}$ \\
Autoclave expansion (\%) & 0.4 & $0.80 \mathrm{max}$ \\
Vicat time of setting (min) & & \\
Initial & 128 & 45 min \\
Final & 235 & 375 max \\
Compressive strength (MPa) & & \\
1 days & 14.5 & - \\
3 days & 20.3 & 10.3 min \\
7 days & 29.2 & 17.2 min \\
28 days & 41 & - \\
Specific gravity & 3.39 & - \\
\hline
\end{tabular}

Table 2. Chemical compositions of Portland cement [42].

\begin{tabular}{lcc}
\hline Constituent & $\begin{array}{c}\text { Results } \\
\text { obtained }\end{array}$ & $\begin{array}{c}\text { ASTM C150 } \\
\text { (type II cement) }\end{array}$ \\
\hline $\mathrm{SiO}_{2}(\%)$ & 21.10 & 20.0 min \\
$\mathrm{Al}_{2} \mathrm{O}_{3}(\%)$ & 4.79 & 6.0 max \\
$\mathrm{Fe}_{2} \mathrm{O}_{3}(\%)$ & 3.80 & 6.0 max \\
$\mathrm{CaO}(\%)$ & 63.09 & - \\
$\mathrm{MgO}(\%)$ & 3.00 & 6.0 max \\
$\mathrm{SO}_{3}(\%)$ & 1.93 & 3.0 max \\
$\mathrm{Na}_{2} \mathrm{O}(\%)$ & 0.20 & - \\
$\mathrm{K}_{2} \mathrm{O}(\%)$ & 0.81 & - \\
$\mathrm{LOI}(\%)$ & 1.24 & 3 max \\
$\mathrm{IR}(\%)$ & 0.63 & $0.75 \max$ \\
$\mathrm{C}_{3} \mathrm{~S}(\%)$ & 48.32 & - \\
$\mathrm{C}_{2} \mathrm{~S}(\%)$ & 24.05 & - \\
$\mathrm{C}_{3} \mathrm{~A},(\%)$ & 6.27 & - \\
$\mathrm{C}_{4} \mathrm{AF}(\%)$ & 11.58 & - \\
$\mathrm{Free} \mathrm{CaO}(\%)$ & 1.22 & \\
\hline
\end{tabular}

chemical compositions of PCIAP are given in Tables 3 and 4, respectively [42]. Natural sand was used as a fine aggregate (regular sand) with a maximum size of $4.8 \mathrm{~mm}$ and was tested to satisfy the requirements of ASTM C33 [43]. Coarse aggregates with the maximum size of $25 \mathrm{~mm}$ were used in this research. Aggregate properties are shown in Table 5 [42].
Table 4. Chemical composition of PCIAP [42].

\begin{tabular}{lccccc}
\hline PCIAP & $\begin{array}{c}\text { Value } \\
(\%)\end{array}$ & PCIAP & $\begin{array}{c}\text { Value } \\
(\mathbf{p p m})\end{array}$ & PCIAP & $\begin{array}{c}\text { Value } \\
(\mathbf{p p m})\end{array}$ \\
\hline $\mathrm{SiO}_{2}$ & 18.25 & $\mathrm{Cl}$ & 772 & $\mathrm{Zr}$ & 71 \\
$\mathrm{Al}_{2} \mathrm{O}_{3}$ & 5.43 & $\mathrm{Ba}$ & 150 & $\mathrm{Y}$ & 4 \\
$\mathrm{Fe}_{2} \mathrm{O}_{3}$ & 27.95 & $\mathrm{Sr}$ & 299 & $\mathrm{Rb}$ & 22 \\
$\mathrm{CaO}$ & 16.21 & $\mathrm{Cu}$ & 80 & $\mathrm{Co}$ & 1 \\
$\mathrm{Na}_{2} \mathrm{O}$ & 1.28 & $\mathrm{Zn}$ & 1543 & $\mathrm{As}$ & 61 \\
$\mathrm{~K}_{2} \mathrm{O}$ & 0.89 & $\mathrm{~Pb}$ & 35 & $\mathrm{U}$ & 1 \\
$\mathrm{MgO} \mathrm{O}$ & 1.37 & $\mathrm{Ni}$ & 110 & $\mathrm{Th}$ & 2 \\
$\mathrm{TiO}_{2}$ & 0.546 & $\mathrm{Cr}$ & 175 & $\mathrm{Mo}$ & 46 \\
$\mathrm{MnO}$ & 0.079 & $\mathrm{~V}$ & 57 & $\mathrm{Ga}$ & 6 \\
$\mathrm{P}_{2} \mathrm{O}_{5}$ & 9.444 & $\mathrm{Ce}$ & 4 & $\mathrm{Nb}$ & 3 \\
$\mathrm{SO}_{3}$ & 2.765 & $\mathrm{La}$ & 1 & & \\
$\mathrm{~L} \mathrm{O} . \mathrm{I}$ & 15.19 & W & 3 & & \\
\hline
\end{tabular}

\subsection{Mixture proportions}

According to ACI Standard Specifications 211.1 [44], mixture proportions of control specimen without PCIAP were designed to achieve a 28-day cube compressive strength of $36.5 \mathrm{MPa}$. Also, five mixtures were prepared with different amounts of PCIAP. The percentage of PCIAP was varied between 5 and $25 \%$ by weight of the cement. The water to binder ratio (w/b) was kept constant at 0.5 for all mixtures. Detailed mix proportions of the concretes are given in

Table 3. Physical properties of PCIAP [42].

\begin{tabular}{lcc}
\hline \multicolumn{1}{c}{ Property } & PCIAP & $\begin{array}{c}\text { Portland cement } \\
\text { type II }\end{array}$ \\
\hline Specific gravity $\left(\mathrm{gr} / \mathrm{cm}^{3}\right)$ & 2.63 & 3.39 \\
Fineness: specific surface (air permeability test) $\left(\mathrm{m}^{2} / \mathrm{kg}\right)$ & 288 & 281 \\
\hline
\end{tabular}


Table 5. Physical properties of coarse aggregates and regular sand [42].

\begin{tabular}{lccc}
\hline \multicolumn{1}{c}{ Property } & $\begin{array}{c}\text { Coarse aggregate } \\
\mathbf{( 2 5} \mathbf{~ m m})\end{array}$ & $\begin{array}{c}\text { Regular sand } \\
\text { (fine aggregate) }\end{array}$ & $\begin{array}{c}\text { ASTM } \\
\text { C33 }\end{array}$ \\
\hline Specific gravity & 2.7 & 2.6 & - \\
Unit weight $\left(\mathrm{kg} / \mathrm{m}^{3}\right)$ & 1670 & 1760 & - \\
Absorption $(\%)$ & 0.5 & 0.7 & - \\
Fineness modulus & - & 2.4 & $2.3-3.1$ \\
Clay lumps and friable particles $(\%)$ & - & 0.4 & 3 max \\
Materials finer than $75 \mu \mathrm{m}(\%)$ & - & 0.8 & 3 max \\
Total moisture content $(\%)$ & 1 & 5 & - \\
\hline
\end{tabular}

Table 6. Mixture proportions of concrete mixtures containing PCIAP [42].

\begin{tabular}{lcccccc}
\hline Mixture no. & M-1 & M-2 & M-3 & M-4 & M-5 & M-6 \\
\hline Cement $\left(\mathrm{kg} / \mathrm{m}^{3}\right)$ & 362 & 343.9 & 325.8 & 307.7 & 289.6 & 271.5 \\
PWIAP $(\%)$ & 0 & 5 & 10 & 15 & 20 & 25 \\
PWIAP $\left(\mathrm{kg} / \mathrm{m}^{3}\right)$ & 0 & 18.1 & 36.2 & 54.3 & 72.4 & 90.5 \\
Water $\left(\mathrm{kg} / \mathrm{m}^{3}\right)$ & 181 & 181 & 181 & 181 & 181 & 181 \\
W/C & 0.5 & 0.5 & 0.5 & 0.5 & 0.5 & 0.5 \\
Sand $(4.8 \mathrm{~mm})\left(\mathrm{kg} / \mathrm{m}^{3}\right)$ & 705 & 705 & 705 & 705 & 705 & 705 \\
Coarse aggregate $(25 \mathrm{~mm})\left(\mathrm{kg} / \mathrm{m}^{3}\right)$ & 1197 & 11.97 & 11.97 & 1197 & 1197 & 1197 \\
\hline
\end{tabular}

Table 6. Concrete mixes were prepared in power-driven revolving-type drum mixers with a capacity of $0.25 \mathrm{~m}^{3}$.

\subsection{Preparation and casting of test specimens}

Fresh concrete was cast into $150 \times 150 \times 150 \mathrm{~mm}$ cubes for compressive strength test, $150 \times 300 \mathrm{~mm}$ cylinders for splitting-tensile strength and modulus of elasticity tests, and $101.4 \times 101.4 \times 508 \mathrm{~mm}$ prismatic molds for flexural strength test. The specimens were compacted using a tamping rod to exclude the air bubbles from the concrete. In order to minimize the moisture loss, the samples were covered. Subsequently, the test samples were placed in the casting room with a temperature of $23^{\circ} \mathrm{C}$. Eventually, the specimens were demolded 24 hours after casting and cured in water at $23 \pm 3^{\circ} \mathrm{C}$ until they were tested.

\subsection{Test procedure}

Slump test was performed according to the ASTM Standard Specifications C143 [45]. Hardened specimens were tested at 7-, 28-, and 90-day ages in accordance with the ASTM Standard Specifications C39, C642, C496, C469, and C293 [46-50].

\section{Results and discussions}

\subsection{Slump test}

The slump test results of the fresh concrete used to determine the effects of the PCIAP on the consistency are given in Figure 1. According to Figure 1, the slump value of the fresh concrete for concrete mixtures with PCIAP was higher than control mixture. Concrete

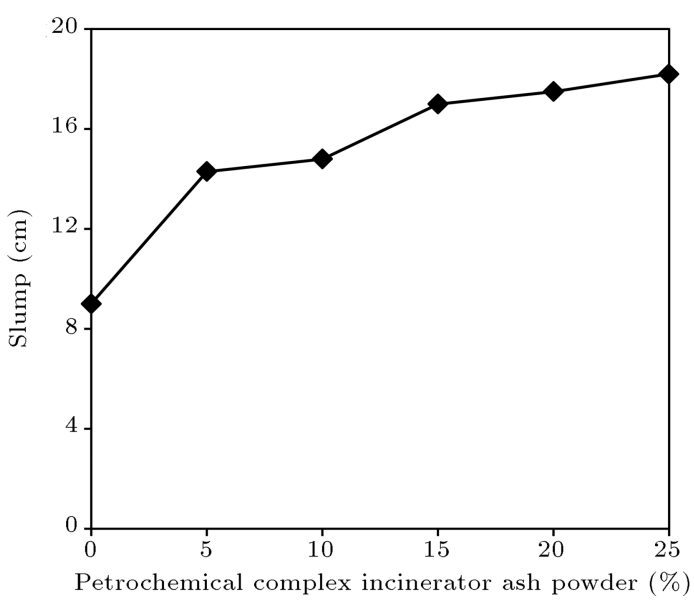

Figure 1. The effect of the PCIAP on the slump behavior.

mixtures with PCIAP had an increase of slump value in comparison with control mixture (see Figure 2). It is perceived that the PCIAP increases the slump value of the fresh concrete and the fluidity. This is probably due to $\mathrm{Fe}_{2} \mathrm{O}_{3}$ content present in PCIAP or due to the decrease of binder value in concrete, in which increasing the fluidity of the fresh concrete is effective.

\subsection{Compressive strength}

Compressive strength of concrete mixtures made with and without PCIAP was measured at age of 7,28 , and 90 days of curing. The results are shown in Figure 3 [42]. According to Figure 3, compressive strength of concrete mixtures with PCIAP was lower 


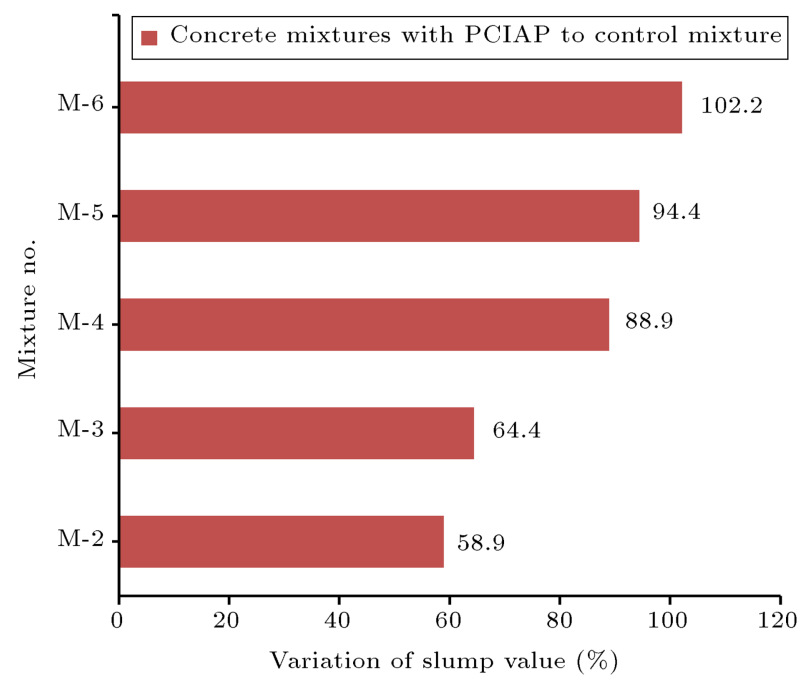

Figure 2. A comparison of slump value variation.

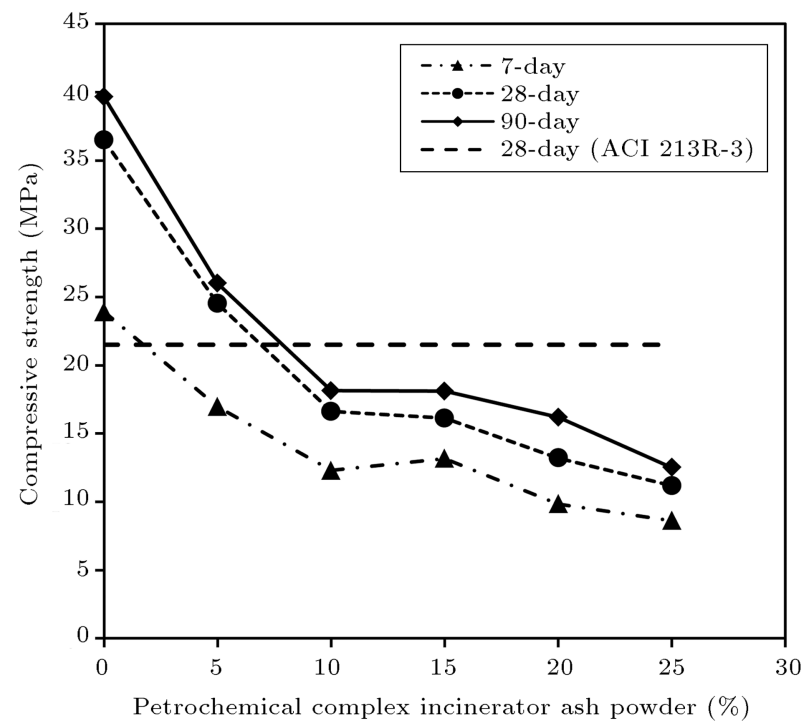

Figure 3. Compressive strength in relation to PCIAP and curing age [42].

than control mixture (without PCIAP). It could be due to the presence of $\mathrm{Fe}_{2} \mathrm{O}_{3}$ in PCIAP, but compressive strength of concrete mixtures increased with age. In Figure 4, at 28 days, percentage decrease in compressive strength of concrete mixtures made with PCIAP was more than that of control mixture. According to Figure 4, with the age of 28 to 90 days, percentage increase in compressive strength of concrete mixtures made with PCIAP was more than that of control mixture except mixture M-2, which is certainly by virtue of increasing the pozzolanic reaction with time. Taha et al. [6] indicated similar results, as they reported that concretes made with incinerator fly ash achieved low compressive strength at ages of 3 to 6 months, but it achieved high compressive strength later than 6 months due to an increase in pozzolanic reaction with time. According to ACI classifications

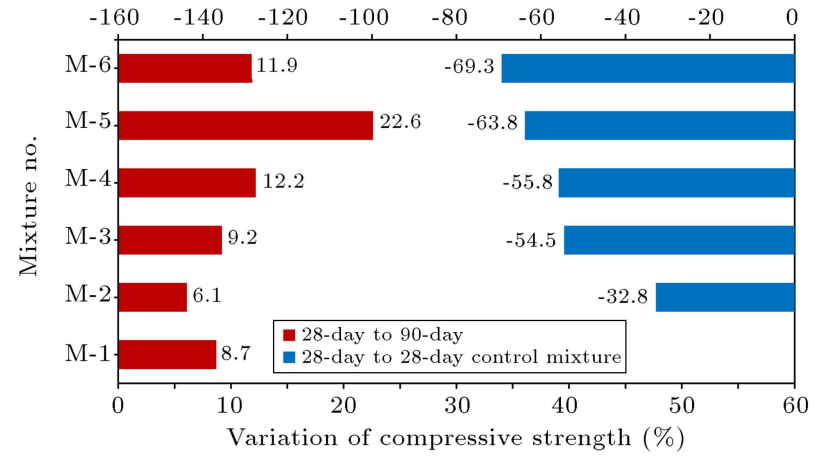

Figure 4. Multiple comparisons of compressive strength variation.

[51], structural lightweight aggregate concrete (LWAC) is concrete in which its air-dry unit weight at 28 days is usually in the range of 1440 to $1900 \mathrm{~kg} / \mathrm{m}^{3}$, and it has a minimum compressive cylindrical strength of $17.2 \mathrm{MPa}$ at 28 days. According to UNESCO [52], compressive strength of cylindrical specimen was converted to cube specimen. At 28-day age, compressive cubic strength of mixture M-2 was 24.5 MPa, higher than the ACI 213R-87 [51] allowable limits [42].

\subsection{Splitting-tensile strength}

The splitting-tensile strength of concrete mixtures was determined at 7,28 , and 90 days of curing. The results are shown in Figure 5. Splitting tensile strength of concrete mixtures increased with age. As can be seen in Figure 6, at 28-day age, concrete mixtures with PCIAP had a decrease of splitting-tensile strength in comparison with control mixture. At 90-day age, all concrete mixtures had an increase of splittingtensile strength in comparison with 28-day strength (see Figure 6). At 90-day age, there was a marginal increase in splitting-tensile strength of mixture M-2 in comparison with control mixture. Also, there was a

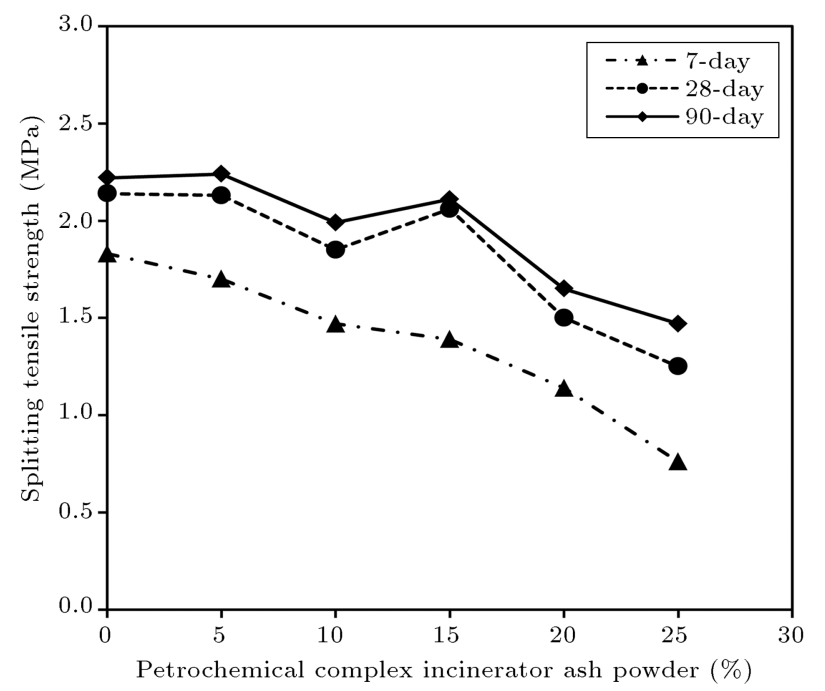

Figure 5. Splitting-tensiling strength in relation to PCIAP and curing age. 


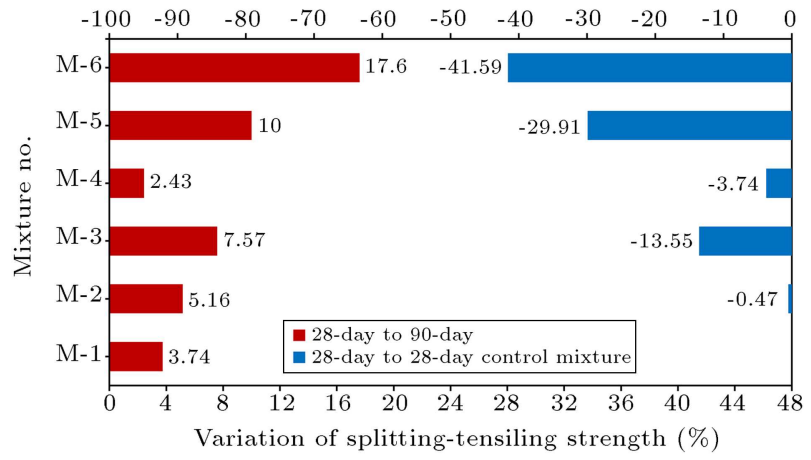

Figure 6. Multiple comparisons of splitting-tensiling strength variation.

slight increase in splitting-tensile strength of mixture M-4 in comparison with mixture M-3 at 28 and 90 days. According to the results, $5 \%$ PCIAP replacement can be considered as the optimum percentage of the PCIAP. The mixtures containing more than 5\% PCIAP had splitting-tensile strength lower than the control mixture.

\subsection{Flexural strength}

Flexural strength of concrete mixtures made with and without PCIAP was determined at ages of 7,28 , and 90 days. The flexural strength test results of concrete mixtures are shown in Figure 7. At 28-day age, concrete mixtures with PCIAP had a decrease of flexural strength in comparison with control mixture. As can be clearly seen from Figure 7, it is evident that flexural strength of samples increased with the age. There is a decrease in flexural strength of concrete mixtures by fostering the content of PCIAP at 28-day age in comparison with control mixture (see Figure 8), such as compressive and splitting tensile strengths. At 90-day age, all concrete mixtures had an increase of flexural strength in comparison with 28-day strength

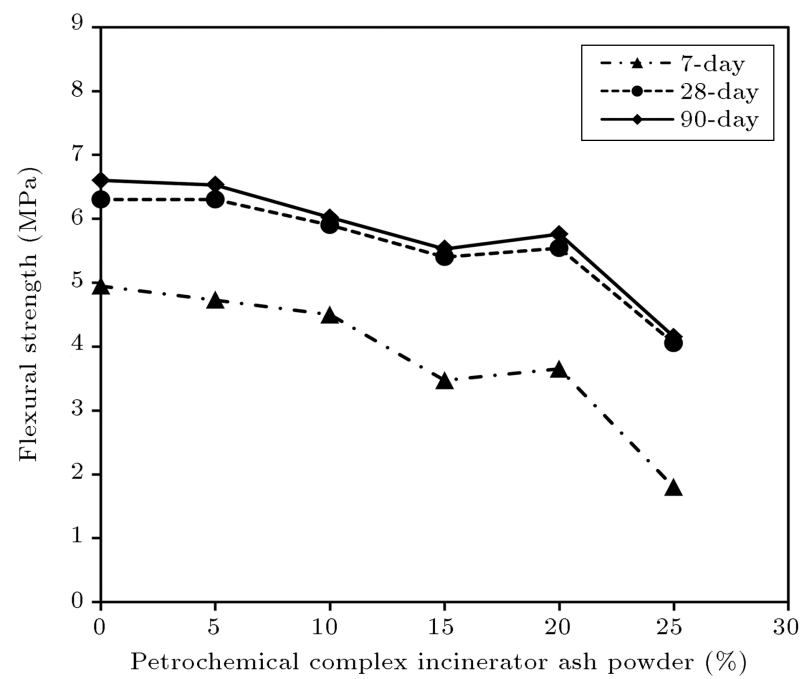

Figure 7. Flexural strength in relation to PCIAP and curing age.

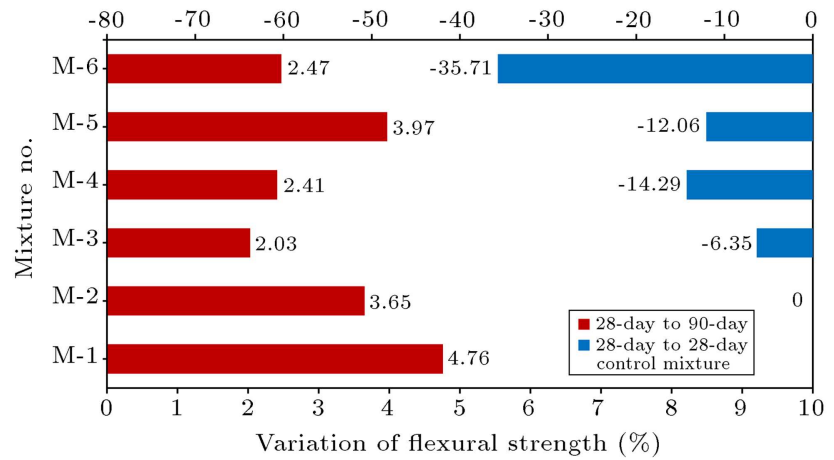

Figure 8. Multiple comparisons of flexural strength variation.

(see Figure 8). At 7, 28, and 90 days, there was a marginal increase in flexural strength of mixture M5 in comparison with mixture M-4. At 28 and 90 days, flexural strength of concrete mixtures decreased with the increase in PCIAP content in comparison with mixture M-1, such as compressive strength.

\subsection{Modulus of elasticity}

The modulus of elasticity was determined according to ASTM C469 [49]. This test method covered determination of chord modulus of elasticity (Young's). The modulus of elasticity $(E)$ was calculated according to the equation suggested by ASTM C469. The formula appears in Eq. (1):

$$
E=\left(S_{2}-S_{1}\right) /\left(\varepsilon_{2}-0.000050\right),
$$

where $E$ is chord modulus of elasticity in psi, $S_{2}$ is stress corresponding to $40 \%$ of ultimate load in psi, $S_{1}$ is stress corresponding to longitudinal strain, $\varepsilon_{1}$, of 50 millionths, psi, and $\varepsilon_{2}$ is longitudinal strain produced by stress, $S_{2}$. Modulus of elasticity of concrete mixtures was determined at 7, 28, and 90 days, and the results are plotted in Figure 9. At 28-day age,

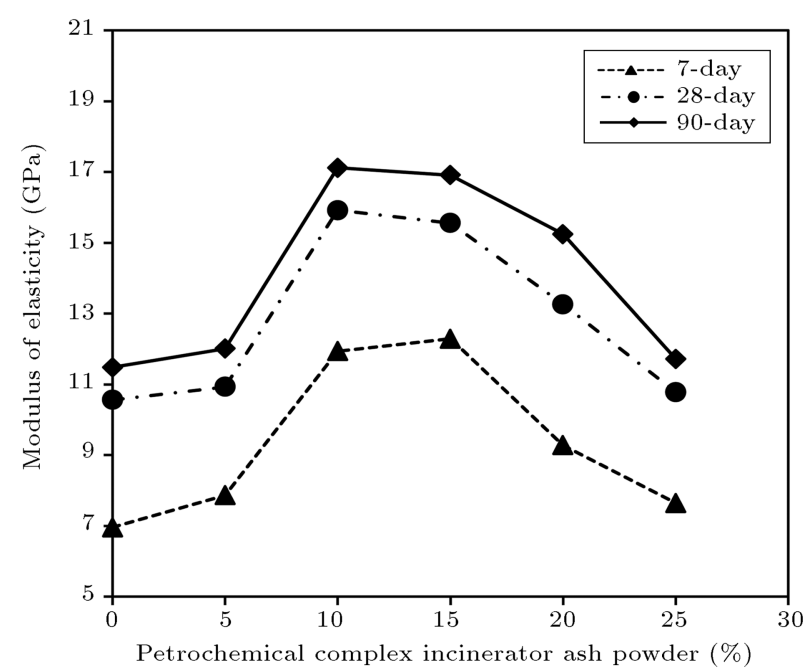

Figure 9. Modulus of elasticity in relation to PCIAP content and curing. 


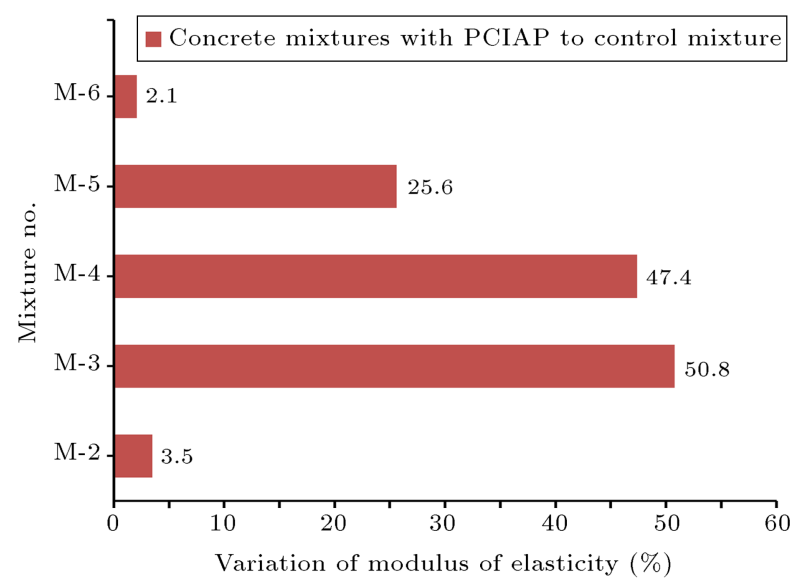

Figure 10. A comparison of modulus of elasticity variation.

concrete mixtures incorporating PCIAP demonstrated an increase in modulus of elasticity compared with the control mixture (see Figure 10). It is also evident that modulus of elasticity of all mixtures increased with the age. At 7, 28, and 90 days, modulus of elasticity of concrete mixtures increased with the increase of PCIAP content in comparison with control mixture. In this study, the 10\% PCIAP replacement can be considered as the optimum percentage of the PCIAP.

\subsection{Water absorption}

The water absorption test was performed for each concrete mixture at of 7-, 28-, and 90-day age. From each mixture, three cubical samples were weighed and submerged for an hour, then taken out from the water and weighed again. Later, the samples were kept dry for two days. Again, the samples were weighed and submerged for a day, after which they were taken out and the weights of the samples were measured. The water absorption values of the samples with and without the PCIAP are provided in Figure 11. At

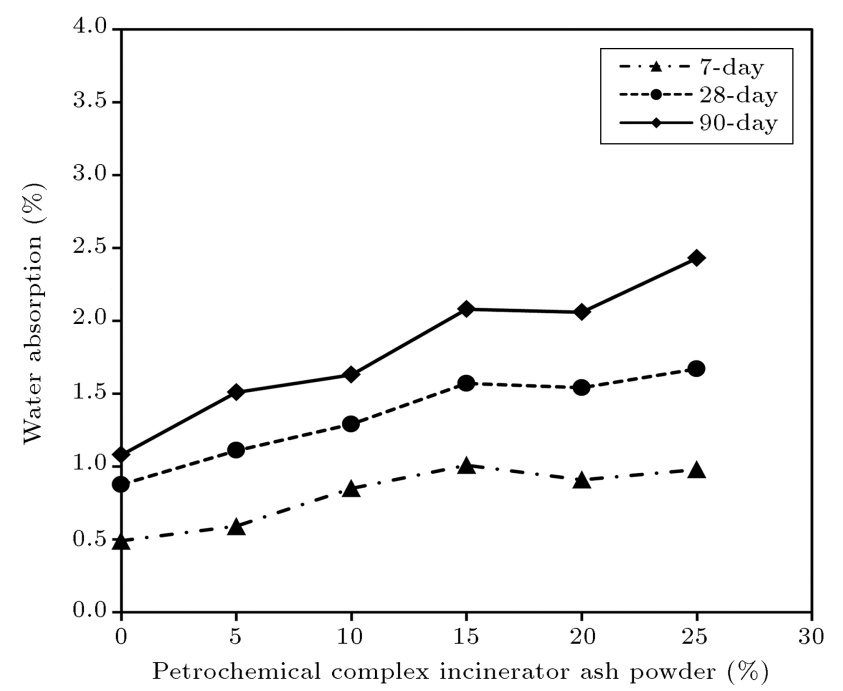

Figure 11. Effect of PCIAP content on water absorption. 28-day age, there was an increase in water absorption of concrete mixtures with the inclusion of PCIAP as partial replacement of Portland cement type II (see Figure 11). Also, at 7 and 90 days, there were similar results such as those at 28 days. Also, water absorption of concrete mixtures also increased with age. These may be explained as the consumption of PCIAP increases the void in the concrete. This investigation indicated an enhancement in water absorption of concrete mixtures made with PCIAP.

\subsection{Unit weight}

The unit weight test results of concrete mixtures are shown in Figure 12. At 28-day age, there was a decrease in unit weight of concretes mixtures with the inclusion of PCIAP as partial replacement of Portland cement type II (Figure 12). At 28-day age, unit weight of concrete mixtures decreased with the increase in PCIAP content in comparison with control mixture (see Figure 13). This could be due to the lower specific gravity of the PCIAP in comparison with Portland cement type II. This investigation

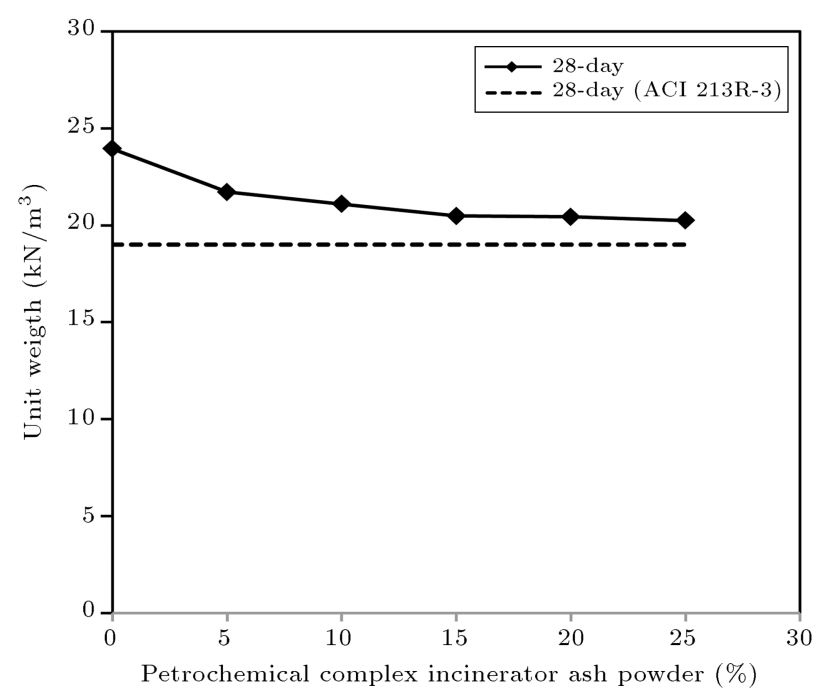

Figure 12. Unit weight versus PCIAP content.

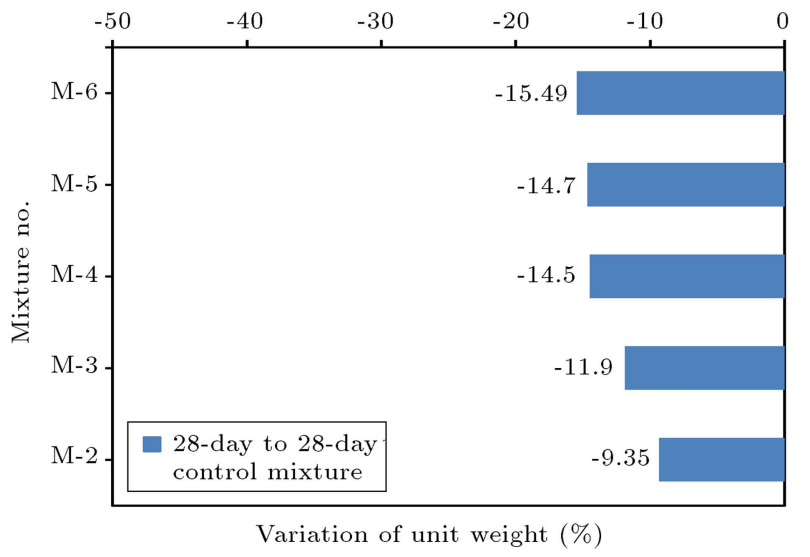

Figure 13. A comparison of unit weight variation. 
indicated that concrete mixtures made with PCIAP were lighter than control mixture. According to ACI 213R-87 [51], structural LWAC has a maximum air-dry unit weight of $1900 \mathrm{~kg} / \mathrm{m}^{3}$ at 28 days (see Figure 12). Unit weights of concrete mixture with the inclusion of PCIAP were higher than the ACI code allowable limits, but were lower than normal concrete.

\section{Conclusions}

The following conclusions can be drawn based on the present investigation:

1. Compressive strength, flexural strength, and unit weight of concrete mixtures decreased with the increase in PCIAP contents in comparison with control mixture;

2. In splitting-tensile strength, the $5 \%$ amount of replacement of PCIAP could be the optimum percentage of the PCIAP. The mixtures containing more than $5 \%$ PCIAP had splitting-tensile strength lower than the control mixture;

3. By modulus of elasticity assessment, it can be concluded that $10 \%$ replacement of PCIAP is the optimum percentage;

4. Water absorption, fluidity, and slump value of the fresh concrete were boosted in PCIAP-containing mixtures;

5. The test results proved that $5 \%$ PCIAP can be used as cement substitution in concrete which was lighter than normal concrete and heavier than structural LWAC. Also, the compressive strength was higher than ACI 213R-87 estimated compressive strength value for 28-day age;

6. Using PCIAP as cement substitution in concrete resulted in the process of $\mathrm{S} / \mathrm{S}$ and neutralization to eliminate the adverse environmental impacts;

7. It can be inferred from the results that concrete mixture containing 5\% PCIAP has many benefits, such as reduction in contaminations of cement production, dead loads, energy consumption; the reduction occurs using the natural resources for cement production and costs elimination of treatment, burial, and transportation of PCIAP.

\section{References}

1. Abduli, M.A., Abbasi, M., Nasrabadi, T., Hoveidi, H. and Razmkhah, N. "Solid waste management in Tabriz petrochemical complex", Iran. J. Environ. Health. Sci. Eng., 3(3), pp. 185-192 (2006).

2. U.S. Environmental Protection Agency "Technology performance review: Selecting and using solidification/stabilization treatment for site remediation",
U.S. Environmental Protection Agency, Document No. EPA/600/R-09/148, Cincinnati, Ohio (2009).

3. Poon, C.S., Kou, S.C. and Lam, L. "Use of recycled aggregates in molded concrete bricks and blocks", Constr. Build. Mater., 16(5), pp. 281-289 (2002).

4. Amaya, P.J. "Boiler slag and bottom ash in asphalt concrete", Proc., 12th Int. Symposium on Coal Combustion By-Products (CCB) Management and Use, American Coal Ash Association, 1, Alexandria, Virginia (1997).

5. Ksaihati, K. and Stephen, J., Utilization of Bottom Ash in Asphalt Mixes, Department of Civil and Architectural Engineering, Laramie, WY: University of Wyoming, pp. 82071-83295 (1999).

6. Taha, R.A., Delwar, M., Ali, G., Al-Harthy, A. and Al-Oraimi, S. "Use of municipal solid waste incinerator ash in Portland cement concrete", Proc., 4th Int. Symposium on Environmental Geo-Technology and Global Sustainable Development, 1, Boston, M.A., pp. 441500 (2000).

7. Juric, B., Hanzic, L., Ilic, R. and Samec, N. "Utilization of municipal solid waste bottom ash and recycled aggregate in concrete", Waste Manag., 26(12), pp. 1436-1442 (2006).

8. Rivard-Lentz, D.J., Sweeney, L.R. and Demars, K. "Incinerator bottom ash as a soil substitute: physical and chemical behavior", Proceedings of the Symposium on Testing Soil Mixed with Waste or Recycled Materials, ASTM STP 1275, pp. 246-262 (1997).

9. Ghafoori, N. and Bucholc, J. "Properties of bottom ash-based composite", Proceedings of the Session on Utilization of Industrial Byproducts for Construction Materials, American Society of Civil Engineers, pp. 5265 (1993).

10. Gress, D., Zhang, X., Tarr, S., Pazienza, I. and Eighmy, T. "Physical and environmental properties of asphalt amended bottom ash", Trans. Res. Record 1345, Transportation Research Board, Washington, DC: NRC, pp. 10-18 (1992).

11. Dewey, G.R., Movrich, M.L. and Cousino, M.T. "Municipal waste combustor ash as an aggregate substitute in bituminous mixtures", Proceedings of the Symposium on Recovery and Effective Reuse of Discarded Materials and by-Products for Construction of Highway Facilities, Federal Highway Administration and Environmental Protection Agency, Denver, CO, USA (1993).

12. Ferguson, G. "Use of self-cementing fly ashes as a soil stabilizing agent", Proceedings of the ASCE Annual Convention and Exposition, ISBN 0-87262-968-4, Dallas, TX, pp. 1-14 (1993).

13. U.S. Environmental Protection Agency, "Stabilization/solidification of CERCLA and RCRA wastes", U.S. Environmental Protection Agency, Document No. EPA/625/6-89/022, Cincinnati, Ohio (1989).

14. Pojasek, R.B., Toxic and Hazardous Waste Disposal, Processes for Stabilization/Solidification, Michigan, U.S.: Ann Arbor Science Publishers Inc (1979). 
15. U.S. Environmental Protection Agency, Applications Analysis Report Soliditech, Inc. Solidification/Stabilization Process, U.S. Environmental Protection Agency, Document No. EPA/540/A5-89/005, Cincinnati, Ohio (1990).

16. Forteza, R., Far, M., Segui, C. and Cerda, V. "Characterization of bottom ash in municipal solid waste incinerators for its use in road base", Waste Manag., 24(9), pp. 899-909 (2004).

17. Chan, Y.M. "Waste management and treatment in an automobile brake manufacturing facility", M. Tech Thesis, Kuala Lumpur, University Malaya, pp. 51-56, 77- 92 (1999).

18. Pecqueur, G., Crignon, C. and Que'ne'e, B. "Behaviour of cement-treated MSWI bottom ash", Waste Manage., 21(3), pp. 229-233 (2001).

19. Ferraris, M., Salvo, M., Ventrella, A., Buzzi, L. and Veglia, M. "Use of vitrified MSWI bottom ashes for concrete production", Waste Manage., 29(3), pp. 1041-1047 (2009).

20. Kikuchi, R. "Recycling of municipal solid waste for cement production: Pilot-scale test for transforming incineration ash of solid waste into cement clinker", Resour. Conserv. Recycl., 31(2), pp. 137-147 (2001).

21. Saikia, N., Kato, S. and Kojima, T. "Production of cement clinkers from municipal solid waste incineration (MSWI) fly ash", Waste Manag., 27(9), pp. 1178-1189 (2007).

22. Biyani, R.K., Agamuthu, P. and Mahalingam, R. Polyester Resin Microencapsulation in Hazardous and Radioactive Waste Treatment Technologies Handbook, New York: CRC Press (2001).

23. Pan, J.R., Huang, C., Kuo, J.J. and Lin, S.H. "Recycling MSWI bottom and fly ash as raw materials for Portland cement", Waste. Manag., 28(7), pp. 11131118 (2008).

24. Chen, C.H. and Chiou, I.J. "Distribution of chloride ion in MSWI bottom ash and de-chlorination performance", J. Hazard. Mater., 148(1-2), pp. 346-352 (2007).

25. Krammart, P. and Tangtermsirikul, S. "A study on cement made by partially replacing cement raw materials with municipal solid waste ash and calcium carbide waste", Sci. Asia, 29, pp. 77-84 (2003).

26. Shi, H.S., Deng, K., Yuan, F. and Wu, K. "Preparation of the saving-energy sulfoaluminate cement using MSWI fly ash", J. Hazard. Mater., 169(1-3), pp. 551555 (2009).

27. Siddique, R. "Use of municipal solid waste ash in concrete", Resour. Conserv. Recycl., 55(2), pp. 83-91 (2010).

28. Siddique, R. "Utilization of municipal solid waste (MSW) ash in cement and mortar", Resour. Conserv. Recycl., 54(12), pp. 1037-1047 (2010).

29. McCarthy, M.J. and Dhir, R.K. "Development of high volume fly ash cements for use in concrete construction", Fuel., 84(11), pp. 1423-1432 (2005).
30. Aubert, J.E., Husson, B. and Vaquier, A. "Use of municipal solid waste incineration fly ash in concrete", Cem. Concr. Res., 34(6), pp. 957-963 (2004).

31. Kula, I., Olgun, A., Sevinc, V. and Erdogan, Y. "An investigation on the use of tincal ore waste, fly ash, and coal bottom ash as Portland cement replacement materials", Cem. Concr. Res., 32(2), pp. 227-232 (2002).

32. Uchikawa, H. and Obana, H. "Ecocement-Frontier of recycling of urban composite waste", World Cem., 26(11), pp. 33-36 (1995).

33. Shih, P.H., Chang, J.E. and Chiang, L.C. "Replacement of raw mix in cement production by municipal solid waste incineration ash", Cem. Concr., 33(11), pp. 1831-1836 (2003).

34. Gines, O., Chimenos, J.M., Vizcarro, A., Formosa, J. and Rosell, J.R. "Combined use of MSWI bottom ash and fly ash as aggregate in concrete formulation: Environmental and mechanical considerations", J. Hazard. Mater., 169(1-3), pp. 643-650 (2009).

35. Lin, Y.C., Yen, J.H., Lateef, S.K., Hong, P.K.A. and Lin, C.F. "Characteristics of residual organics in municipal solid waste incinerator bottom ash", $J$. Hazard. Mater., 182(1-3), pp. 337-345 (2010).

36. Rebeiz, K.S. and Mielich, K.L. "Construction use of municipal-solid-waste ash", J. Energy. Eng., 121(1), pp. 2-13 (1995).

37. Pera, J., Coutaz, L., Ambroise, J. and Chababet, M. "Use of incinerator bottom ash in concrete", Cem. Concr. Res., 27(1), pp. 1-5 (1997).

38. Alkemade, M.M.C., Eymael, M.M.Th., Mulder, E. and Wijs, W. "How to prevent expansion of MSWI bottom ash in road construction", Stud. Environ. Sci., 60, pp. 863-876 (1994).

39. Appendino, P., Ferraris, M., Matekovits, I. and Salvo, M. "Production of glass-ceramic bodies from the bottom ashes of municipal solid waste incinerators", $J$. Eur. Ceram. Soc., 24(5), pp. 803-810 (2004).

40. Cheng, T.W., Huang, M.Z., Tzeng, C.C., Cheng, K.B. and Ueng, T.H. "Production of coloured glass-ceramics from incinerator ash using thermal plasma technology", Chemosphere, 68(10), pp. 1937-1945 (2007).

41. ASTM C150-85a, Annual book of ASTM Standards "Standard specification for Portland cement", American Society for Testing and Materials, 04.02, Philadelphia, pp. 114-119 (1986).

42. Noorpour, M., Mousavi, A., Noorpour, S., Karbati Asl, R. and Karbati Asl, A. "Effect of petrochemical complex incinerator ash on the compressive strength of concrete against sulfate and chloride attack", Eur. J. Sci. Res., 114(1), pp. 99-113 (2013).

43. ASTM C33-86, Annual Book of ASTM Standards, Standard Specification for Concrete Aggregates, American Society for Testing and Materials, 04.02, Philadelphia, pp. 11-19 (1986). 
44. American Concrete Institute (ACI), "Standard practice for selecting proportions for normal, heavyweight, and mass concrete", Report ACI 211.1 (2002).

45. ASTM C143-78, Annual Book of ASTM Standards, Standard Test for Slump of Portland Cement Concrete, American Society for Testing and Materials, 04.02, Philadelphia, pp. 109-111 (1986).

46. ASTM C39-86, Annual Book of ASTM Standards, Standard Test Method for Compressive Strength of Cylindrical Concrete Specimens, American Society for Testing and Materials, 04.02, Philadelphia, pp. 24-29 (1986).

47. ASTM C642-82, Annual Book of ASTM Standards, Standard Test Method for Specific Gravity, Absorption, and Voids in Hardened Concrete, American Society for Testing and Materials, 04.02, Philadelphia, pp. 403-405 (1986).

48. ASTM C469-83, Annual book of ASTM Standards, Standard Test Method for Static Modulus of Elasticity and Poisons Ratio of Concrete in Compression, American Society for Testing and Materials, 04.02, Philadelphia, pp. 305-309 (1986).

49. ASTM C496-85, Annual Book of ASTM Standards, Standard Test Method for Splitting Tensile Strength of Cylindrical Concrete Specimens, American Society for Testing and Materials, 04.02, Philadelphia, pp. 337342 (1986).

50. ASTM C293-79, Annual Book of ASTM Standards, Standard Test Method for Flexural Strength of Concrete (Using Simple Beam with Center-Point Loading), American Society for Testing and Materials, 04.02, Philadelphia, pp. 209-211 (1986).

51. Guide for Structural Lightweight Aggregate Concrete. ACI 213R-87 (Reapproved 1999), ACI Committee 213, American Concrete Institute (1999).

52. An International Manual Handbook Written by committee of experts commissioned by UNESCO. ISBN 0-408-70175-7 (1999).

\section{Biographies}

Davood Mostofinejad is a distinguished Professor at the Department of Civil Engineering in Isfahan University of Technology (IUT), Isfahan, Iran. He received his BSc and MSc degrees from Tehran University and Isfahan University of Technology in 1985 and 1987, respectively; moreover, he received his $\mathrm{PhD}$ degree from Carleton University, Ottawa, Canada, in 1997. His research interests include application of FRP composites in concrete and masonry structures, repair and rehabilitation of damaged $\mathrm{RC}$ structures, concrete technology and biological treatment of concrete, and ductility of RC joints and structures.
Samad Noorpour is a Researcher at the Department of Civil Engineering in Islamic Azad University (IAU), Tabriz Branch, Iran. He received his BSc from IAU, Tabriz Branch, Iran. His research interests include waste management, concrete technology, building materials, cement, and binders.

Mojtaba Noorpour is an active member of Young Researchers and Elite Club (YREC), Islamic Azad University (IAU), Tabriz Branch, Iran. He received his MSc in protective structures from Malek Ashtar University of Technology (MUT), Tehran, Iran, and BSc in Civil Engineering from IAU, Tabriz Branch, Iran. He got scholarship for MSc as a brilliant student at MUT. He has eleven patents and several papers that have been published in or submitted to refereed journals. He was a leader of a research project at YREC. Also, he was the top researcher student of the province in 2010 and First-Place among top graduates of Civil Engineering in BSc section, 2011. He is interested in doing a research about replacement materials instead of cement in concrete, waste management, binders, investigation of microstructural, mechanical properties, and chemical resistance of concrete samples made with waste, investigation of geopolymer concretes made with waste and materials, such as fly ash, silica fume, slag, zeolite, and etc., and fiber-reinforced concrete and shotcrete.

Reza Karbati Asl is a Master of Science student at Department of Civil Engineering in University of Tabriz (UT), Tabriz, Iran. He received his BSc in Civil Engineering from IAU, Tabriz Branch, Iran. He is a member of Young Researchers and Elite Club (YREC) of IAU, Tabriz Branch, Iran. His Research interests include waste management, concrete technology, building materials, environmental engineering, and water treatment.

Vahid Sadeghi Balkanlou is a Lecturer at Civil Engineering Department in Islamic Azad University (IAU), East Azerbaijan, Iran. He received his MSc in Structures, and BSc in Civil Engineering from IAU, Tabriz Branch, Iran. He is a member of Young Researchers and Elite Club of IAU, Tabriz Branch, Iran. His Research interests include structures control with dampers, viscous dampers, concrete technology, and seismic analyses \& design of structures.

Ali Karbati Asl received his BSc in Project Management in Payame Noor University, I.R. of Iran. His research interests include waste management, concrete technology, and project management. 